\title{
The implementation of social attitude assessment in elementary schools: A study of Indonesia
}

\author{
Muhamad Taufik Hidayat, Universitas Muhammadiyah Surakarta, Indonesia, mt.hidayat@ums.ac.id, \\ ORCID: 0000-0002-7787-254X \\ Teci Dyan Listya, Universitas Muhammadiyah Surakarta, Indonesia, a510150152@ums.ac.id, ORCID: 0000- \\ 0003-1311-0850
}

\begin{abstract}
The objective of this study was to analyze the implementation of social attitudes consist of honesty, discipline, responsibility, and tolerance in the elementary schools of Karanganyar Regency, Indonesia. The method used in this study was descriptive qualitative with a case study design. Eight informants were recruited consist of teachers as well as students. The techniques that were used in this study were observation and interview. The data analyzed by data reduction, data presentation, and conclusion drawing. The assessment techniques to check data validity were technical triangulation and source triangulation. The results of this study showed that (1) Most teachers did not observe yet their students inside and outside class activity every day. (2) Some teachers take notes every day, some others incidentally. The indicators got from a combination of official guideline and their own. (3) All teachers at least asses two dimensions (discipline and honesty), the others wholly ignored. All teachers at least use two techniques. (4) The teachers follow up on the assessment by informs students periodically (quarterly) and give them praise or advice.
\end{abstract}

Keywords: Elementary Education, Honesty assessment, Discipline assessment, Responsibility assessment, Tolerance assessment

Received: 17.11.2020 Accepted: 10.12.2020 Published: 05.01.2021

\section{INTRODUCTION}

Attitude is an element of personality that influences the way a person behaves. A person's attitude towards an object, idea, or another person will be reflected in how he reacts to what he faces. At present, student's attitudes are increasingly alarming, especially in social attitudes. Social attitudes are moral virtues as a consciousness to realize the harmony of social life, such as honesty, discipline, responsibility, and tolerance. Several unfavorable social attitudes, such as come late, disobey the teacher's instructions, spread hoax, make trouble with friends, and do not cooperate in school, increasingly reported by teachers worldwide.

Attitude assessment requires teachers to understand the characteristics of each student. Emily (2013) states that teachers often do not compile a written attitude instrument because of difficulty preparing. Besides, student attitude is not easy to assess objectively. Students' attitudes can also be influenced by moods and feelings, which can change every day. Attitude assessment does not determine students' level based on their work but selects the learning to help students develop their positive attitude.

According to Nurbudiyani (2013), the purpose of attitude assessment is to obtain accurate information about students' achievement of learning objectives. Precisely, at the level of acceptance, participation, assessment, organization, and internalization. Taxonomy is included in the internalization process, where the attitude component begins from giving attention to the ability to control attitude. Therefore, the element of the attitude assessment mechanism must be comprehensive. A teacher must be objective in providing the assessment. Every day, the teacher must describe students' natural behavior by looking at the students' actions. Then, the teacher can explain the attitude of the students.

Several studies related to social attitude assessment around countries have been conducted. First, Hugh-Jones (2015) reported the validity of different honesty measures with 1531 samples from 15 states related to honesty assessments. Meanwhile, Hidayati, Budiyono, \& Sugiman (2018) developed a scale to measure students' honesty on mathematics learning involved hundreds of middle school students in Indonesia. Second, related to discipline assessments, Putnam, Luiselli, Handler, \& Jefferson (2003) reported two descriptive studies in a public elementary-middle school in the USA to illustrate office referrals' frequency as an evaluative data source. Haider, Khan, Munir, Latif, \& Bari (2012) investigate the 
effects of indiscipline facing secondary school teachers in Pakistan's public and private institutions. Meanwhile, Stanford (2017) evaluated the Positive Behavior Intervention and Support (PBIS) program implemented at an urban elementary school in North Carolina, USA. Third, related to responsibility assessment, Akbay, Capri, \& Gunduz (2013) developed a valid and reliable instrument that measures university students' academic responsibilities in Turkey. On the other side, Hsu, Pan, Chou, \& Lu (2014) in Taiwan examined the factor structure of the Contextual Self-Responsibility Questionnaire (CSRQ) and Personal and Social Responsibility Questionnaire (PSRQ), which are developed to measure student responsibility within the field of physical education. Escartí, Wright, Pascual, \& Gutiérrez (2015) examined a revised Tool for Assessing Responsibility-based Education (TARE) in Spain. The last ones, related to tolerance assessment. Safina \& Abdurakhmanov (2016) developed a pedagogical model of the formation of students' tolerance in multi-ethnic schools in Kazan, Russia. Meanwhile, Çaliskan \& Saglam (2012) analyzed elementary school students' tendencies to tolerance through certain variables in Sakarya, Turkey.

In fact, In Indonesia, not all teachers can implement attitude assessments, especially on social attitudes. Zuhera \& Mislinawati (2017) reported teacher obstacles in assessing student attitudes in the learning process based on the current curriculum at Public Elementary School 14 Banda Aceh. The difficulties are time limitation and a large number of students. Kamiludin \& Suryaman (2017) also revealed that only one of the six informants (teachers) from a pilot elementary school in Yogyakarta implement the assessments properly. Meanwhile, a study from Fitria (2017) explained that teachers do some types of assessments as follows observation assessment (OA), self-assessment (SA), peer assessment (PA), and journal assessment (JA). The teachers implement OA by observing the attitude of students. SA and PA are done every semester. A JA applied incidentally when there are positive or negative events from students. The obstacles faced by teachers are minimal time and difficulty to determine the conclusions because the psychology of grade 1 students are not easy to predict. The last one, Setiawan \& Suardiman (2018), stated that applying the present curriculum at the elementary school raised some problems for teachers. Serious problems emerged in the assessment, especially the assessment of social attitudes. This problem arises because social attitudes have many dimensions and demand assessment in various forms.

Based on the explanation, it can be concluded that attitude assessment in Elementary School in Indonesia is still very needed to be studied. There are only a few studies about the implementation of social attitude assessments. Based on the background, this study's objective is to reveal the implementation of social attitude assessment in the elementary school in Indonesia. The present study's findings would be essential for elementary education parties in Indonesia especially and globally, to create an effective solution for this issue.

\section{METHOD}

\section{Type and Design}

This study is a descriptive qualitative with a case study design. This study focused on teachers' activities in Karanganyar Regency, Indonesia, in terms of implementing social attitude assessment in the current Indonesian curriculum (Kurikulum 2013). The social attitude in the present study is defined as moral virtues as a consciousness to realize the harmony of social life, such as honesty, discipline, responsibility, and tolerance. The authors conducted this study at Elementary Schools in RA Kartini Area, Kebakkramat, Karanganyar Regency, Central Java, Indonesia, because many teachers experienced obstacles in carrying out social attitude assessments. This study was conducted from April to July 2019.

\section{Data and Data Sources}

The data in this study consist of transcripts of in-depth interviews as well as transcripts of observations. The data sources in this study were informants from 4 selected elementary schools (see Table 1). According to Admosphere (2018) socio-economic classification, two elementary schools are classified as middle-high class (A and B), while two others are middle-low class ( $\mathrm{B}$ and $\mathrm{C}$ ). The classification is based on the (average) family of students in each school. The selection criteria as follow: (1) Located in RA Kartini area (2) Have been implemented the current Indonesian curriculum (3) The fifth-grade teachers and the fifth-grade students willing to be informants.

In this study, the authors applied the ethical principles: (1) Obtained informed consent to all informants. (2) Protected informant's confidentiality. (3) Did not apply deceitful practices. (4) Gave informants the right to withdraw from the study. 
Table 1. Description of Informants

\begin{tabular}{|l|l|l|l|l|l|}
\hline No & Initial & Gender & Old & Role & Elementary School \\
\hline 1 & BE & Female & 44 & Teacher & SDN 3 Waru \\
\hline 2 & PY & Male & 45 & Teacher & SDN 2 Pulosari \\
\hline 3 & BD & Female & 36 & Teacher & SDN 1 Waru \\
\hline 4 & Y & Male & 54 & Teacher & SDN 3 Kebak \\
\hline 5 & E & Female & 11 & Student & SDN 3 Waru \\
\hline 6 & A & Female & 11 & Student & SDN 2 Pulosari \\
\hline 7 & P & Male & 11 & Student & SDN 1 Waru \\
\hline 8 & J & Male & 11 & Student & SDN 3 Kebak \\
\hline
\end{tabular}

Note:

SDN 3 Waru and SDN 2 Pulosari are a middle-high class

SDN 1 Waru and SDN 3 Kebak are a middle-low class

\section{Data collection technique}

\section{Observation}

Observations used in this study were participatory observation and straightforward observation. The authors observed the informants (teachers) in assessing both during and outside of class activities. The authors participated in teacher's activities when assessing social attitudes on students.

The aspects have observed from informants (teachers) as follows: (1) Doing observation of student's social attitudes (2) Writing note of student's social attitudes (3) Reporting the social attitude notes to students (4) Signing the notes of social attitudes in the journal assessment (5) Making a recapitulation of student's social attitudes.

\section{Interview}

The interview used in this study was semi-structured. The authors have prepared the draft of the question. The authors conducted several interviews with all informants about the implementation of social attitude assessments by teachers. The question items of the interview as follow:

\section{Teachers}

- Do you observe the social attitudes of your students?

- Do you note the social attitudes of your students?

- Do you note every day the social attitudes of your students on the journal assessment?

- How do you assess the social attitudes based on the curriculum?

- Do you report the social attitude notes to your students every week?

- Do you sign the notes of social attitudes which are written in the journal assessment?

- Do you make a recapitulation of social attitudes every semester?

Students

- Do your teacher always in the class during the class activity?

- Do your teacher always in the class during break time?

- Do your teacher always notes your social attitudes every day?

- Do your teacher writes in the journal assessment when you are honest?

- Do you ever help your friends or your teacher?

- Do you ever give a reward from your teacher because of your social attitudes?

\section{Data Validity}

The authors used two triangulation types, namely source triangulation and technique triangulation, for checking the validity of the data. Source triangulation was used by collecting the data from different parties, namely students and teachers. While the technique triangulation was used by rechecked the data from interviews with the data from observations.

\section{Data analysis technique}

In the present study, the qualitative data analysis process was used, including data reduction, data display, and conclusion drawing (Miles \& Huberman, 1994). At first, the authors transcripted the results 
of an interview with all informants. Then, the authors categorized the verbatim into the dimension of the implementation of assessment. In this part, the authors employed some category tables. Then, the authors analyzed verbatim based on particular themes. After that, the authors formulate the patterns among the implementation of assessment. At last, the authors concluded.

\section{RESULT}

\section{Observe the behavior of students}

Hereby the statements of the teachers related to observation activity.

"I do the observation, but only note the best and the worst (social attitudes of students). I do monitoring, but only report it every three months " (PY)

"Uhm... No, of course (do observation every day). As a teacher, I have many tasks, so it is impossible to observe students one hundred percent (all students every day) ... " (BD)

"Yes, I do, even though not my best effort... I observe every day what students do, and their attitudes change". (BE)

"I do it even though not every day. I only observe in certain times ..." (Y)

Hereby the result of source triangulation from the students.

"Yes ..., If we naughty, crowded, sometimes (being observed by the teacher)" (A)

"Yes! (the teacher) always in class (during break time) and sometimes do observing (our social attitudes)". (P)

"No, (the teacher) more often in her office (during break time). Maybe my teacher does observing (our social attitudes), but I have no idea". (E)

"(The teacher) more often in the office, and I do not know (about our teacher's activity)". (J)

Based on statements from informants supported by observation results, it can be concluded that some of the teachers have observed their students. Some others have only briefly observed. Besides, in the break time, some teachers are more often in their room, so they rarely observe social attitudes at this time.

\section{Take notes and fill in the right assessment instrument.}

Hereby the result of interviews with the teachers,

"Yes, I just noted (in the JA). ... the indicators for 'honesty' are low profile, do not cheating, and doing their assignments by self. ... Yes, (my instruments) suitable with the official guideline. I got the guideline when I joined the (instruction) workshop". (PY)

"Take notes? Not every day, I do it periodically. I don't need to note it every day because I remember my students' social attitudes quite well.... (the indicator of) discipline is obeying the teacher's instruction. ... I arranged my instruments in order to easy to understandable and usable." (BD)

"Sometimes I note it (the observation record) but not every day. I know that is my fault ... For example, the indicator of 'honesty,' reports found items." (BE)

"Sure, I note it (the observation record) to do not forget it. ... Discipline (indicators) are doing the assignment, come and go home in time, praying, obey the rule ... the (instrument) guidelines are provided. " ( $\mathrm{Y})$

To validated the statement of the teachers, the authors collected comments from the students.

"I think my teacher ever (note our social attitudes)." (A)

"Uhm .... (Our teacher) rarely noted all students' social attitudes. She usually noted the best and the worst, the moderate one is not noted." (P)

"I don't know, as far as I know, my teacher just wrote something in her notebook." (E)

"I never knew that my teacher recorded my (social) attitudes." (J)

Based on the results of interviews and observations, it can be concluded that some teachers took notes every day and some others incidentally. Most teachers use the instruments guideline (indicators) 
from the government and also develop their own. Some students know that their social behavior is recorded by their teachers; some others feel they have never been recorded.

\section{Assess all dimensions of social attitudes}

Hereby the statements of the teachers:

"I assessed honesty, discipline, responsibility ... I (did assessment) with journal assessment. For example, today, I noted the best and worst particular social attitude." (PY) " ... mainly honesty, and then discipline ... I did the observation (assessment), Uhm ... I employed questionnaire as well (SA). I think social attitude can not be assessed with a test, so I only use them (OA and SA)." (BD)

"... I assessed honesty, and then discipline ... sure with observation (assessment). During class activity and also during break time ... I also did peer assessment and selfassessment". (BE)

"... among classmates, among students and teachers. Uhm, 'honesty'. Everything related to the social life of students in the school" (Y)

Based on the statement and observation result, it can be concluded that the teacher's asses primarily assess the honesty dimension. Honesty is claimed as the easiest one to be assessed. Teachers prefer to use JS and OA techniques.

\section{Follow up on the assessments.}

This part is the interview results to the teachers related to the follow-up of their social attitude assessment:

"By informing them periodically about their social attitudes." (PY)

"I do not inform the students about their social attitudes during a week and give them some advice. The social attitudes note is only for my note. I do classical counseling first, but if any special condition, I do counseling individually." (BD)

"Well ... If any student did a good social attitude, I give him praises to maintains his good social attitude." (BE)

"Sure, I remind a student with bad social attitudes. For example, a student who rarely does homework rarely does the assignment, and rarely worship has to be reminded." (Y)

Furthermore, the authors interviewed the students about the follow-up by their teachers:

"(Our teacher) give a reward from our honesty social attitudes in the form of stationery, money, or praise". (A)

"The reward is praise, but I never got it..." (P)

"(Our teacher) Never informed the note (of our social attitudes) ". (E)

"(Our teacher) Never give a reward, and rarely informed the note (of our social attitudes)" (J)

Based on the statements, it can be concluded that the teacher follows up on students' social attitudes by informing them periodically. Then the students were never be rewarded for the development of their social attitudes. The description of emergent themes is summarized in Table 2 .

Table 2. Description of Emergent Themes

\begin{tabular}{|l|l|l|}
\hline No & Theme & Findings \\
\hline 1 & $\begin{array}{l}\text { Observe the behavior of } \\
\text { students }\end{array}$ & $\begin{array}{l}\text { Most teachers did not observe yet their students inside and } \\
\text { outside class activity every day. }\end{array}$ \\
\hline 2 & $\begin{array}{l}\text { Take notes and fill in the } \\
\text { right assessment } \\
\text { instrument. }\end{array}$ & $\begin{array}{l}\text { Some teachers take notes every day, some others incidentally. The } \\
\text { indicators got from a combination of official guideline and their } \\
\text { own. }\end{array}$ \\
\hline 3 & $\begin{array}{l}\text { Assess all dimensions of } \\
\text { social attitudes }\end{array}$ & $\begin{array}{l}\text { All teachers at least asses two dimensions (discipline and honesty), } \\
\text { the others wholly ignored. All teachers at least use two techniques } \\
\text { (JA, OA). Only one teacher use all techniques (OA, PA, JA, SA) }\end{array}$ \\
\hline 4 & Follow up the & The teachers follow up on the assessment by informs students \\
\hline
\end{tabular}




\section{DISCUSSION}

Based on the author's findings, each school has a different way of assessing social attitudes. In three elementary schools, the authors found that teachers observed students' social attitudes during class activity and outside class activity. However, the teachers did not do it every day and every time. Teachers were more often outside the classroom during break time because they have some side jobs. This finding is in line with other studies (Fitria, 2017; Kamiludin \& Suryaman, 2017; Maba, 2019; Zuhera \& Mislinawati, 2017) that time limitation is the central issue of the implementation of social attitude assessment.

There was one teacher who did not determine and inform which indicators would be used in her assessment. Some teachers only reported what social attitudes students must have. Besides, only one teacher who used the four types of social attitude assessment technique. The other ones were not skilled yet because there are too many competencies. This problem may be solved if there are ready to use instruments (in the local context). The teachers can adopt and modify the instruments from various studies such as Hugh-Jones (2015) and Hidayati, Budiyono, \& Sugiman (2018) for honesty assessments, Akbay, Capri, \& Gunduz (2013), Hsu, Pan, Chou, \& Lu (2014), and Escartí, Wright, Pascual, \& Gutiérrez (2015) or responsibility assessment.

The next implementation phase is the follow-up after assessing social attitudes. Teachers must report the results of observations, which are then included in the list of values of social attitudes. All teachers have noted that even though the methods used were different. Some informed classically, small groups, as well as individually. The submission of teachers was made varies because it depends on the situations and conditions. The teachers reported the social attitudes assessment officially at report card day every semester.

Only two teachers applied the right step in making a description of social attitudes. The proper steps did by teachers as follow: (1) teachers classified or marked the attitudes of students written in social attitudes JA, (2) teachers made a recapitulation of attitudes within one semester (3) teachers collected the social attitude notes in the form of brief descriptions of special teachers (religion and physical education) and school staffs (extracurricular teachers, librarian, janitors, and school guards) (4) teachers concluded and formulated descriptions of the social attitudes of each student. The attitude description used motivational sentences with positive word choices. (5) If students did not have any notes in the JA, their social attitude was assumed to be good. Because social attitudes are developed during one semester, descriptions of students' social attitude values were formulated at the end of the semester. The two others have not followed the steps 1 and 2 and used a "memory" and an "assumption" only in step 4 and 5.

\section{CONCLUSION}

Previous studies related to the social attitudes assessment are limited to separated dimensions. A comprehensive social attitudes assessment receive a lack of formal research. The present study revealed the implementation of social attitudes assessment comprehensively. The present study's findings would be essential for all elementary education parties to create an effective solution for this issue.

The present study has several limitations. At first, it is related to the diversity of informants. Informants only selected from RA Kartini area, Karanganyar Regency, made the data less diverse. Second, the study duration was less than a year, so the data was not entirely comprehensive. At last, some informants (students) answered the questions unclearly. Future studies about implementing social attitudes assessment would be better with more representative informants (from various islands) in a whole year study.

This study has three suggestions. First, the elementary schools' headmasters in Indonesia should enrich the teachers' knowledge and insight related to social attitude assessment. Enrichment can be in the form of the following workshops or reading the up to date scientific paper or assessment guideline. Second, elementary school teachers in Indonesia have to employ PA more seriously. The last one, the government, supported by researchers, has to design an excellent assessment system to solve time limitations.

\section{REFERENCES}

Admosphere, N. (2018). ABCDE Socio-economic classification Specification for year 2019. Retrieved from https://www.nielsen-admosphere.cz/wp-content/uploads/2018/12/Nielsen-Admosphere-ABCDE- 
classification-specification-2019.pdf

Akbay, S. E., Capri, B., \& Gunduz, B. (2013). development of the academic responsibility. International Journal of Academic Research Part B, 5(4), 440-446. Retrieved from 10.7813/2075-4124.2013/54/B.64

Çaliskan, H., \& Saglam, H. İ. (2012). A Study on the Development of the Tendency to Tolerance Scale and an Analysis of the Tendencies of Primary School Students to Tolerance Through Certain Variables. Educational Sciences: Theory \& Practice, 12(2), 1440-1445. Retrieved from https://toad.halileksi.net/sites/default/files/pdf/tendency-to-tolerance-scale-toad.pdf

Emily, R. (2013). Assesing affective Learning Using Student Respon System. Libraries \& The Academy, 13(4), 385-401. https://doi.org/10.1353/pla.2013.0037

Escartí, A., Wright, P., Pascual, C., \& Gutiérrez, M. (2015). Tool for Assessing Responsibility-based Education (TARE) 2.0: Instrument Revisions, Inter-rater Reliability, and Correlations between Observed Teaching Strategies and Student Behaviors. Universal Journal of Psychology, 3(2), 55-63. https://doi.org/10.13189/ujp.2015.030205

Fitria, M. Z. (2017). Pelaksanaan penilaian sikap siswa pada kurikulum 2013 kelas i di sd negeri 1 tanjung boyolali [The Implementation of Attitude Assesment of First Grade Student of SDN 1 Tanjung Boyolali Elementary School] (Universitas Muhammadiyah Surakarta). Retrieved from http://eprints.ums.ac.id/54218/1/NASKAH PUBLIKASI.pdf

Haider, Z., Khan, H., Munir, F., Latif, F., \& Bari, S. (2012). Analysis and Evaluation of Discipline Issues in Public and Private Sector Institutions. International Journal of Academic Research in Progressive Education and Development, 1(1), 113-125. Retrieved from http://hrmars.com/admin/pics/678.pdf

Hidayati, K., Budiyono, B., \& Sugiman, S. (2018). Developing scale to measure student's honesty characters on mathematics learning using subject scaling. Jurnal Penelitian Dan Evaluasi Pendidikan, 22(2), 143-153. https://doi.org/10.21831/pep.v22i2.19310

Hsu, W. T., Pan, Y. H., Chou, H. S., \& Lu, F. J. H. (2014). Measuring student responsibility in physical education: Examination of CSR and PSR models. South African Journal for Research in Sport, Physical Education and Recreation, 36(2), 129-136. Retrieved from https://www.ajol.info/index.php/sajrs/article/view/108807

Hugh-Jones, D. (2015). Ways to measure honesty: a new experiment and two questionnaires.

Kamiludin, K., \& Suryaman, M. (2017). Problematika pada pelaksanaan penilaian pembelajaran Kurikulum 2013 [Problems on Implementation of Learning Assesment of Curriculum 2013]. Jurnal Prima Edukasia, 5(1), 58-67. https://doi.org/10.21831/jpe.v5i1.8391

Maba, W. (2019). Teacher's perception on the implementation of the assessment process in 2013 curriculum. International Journal of Social Sciences and Humanities, 1(2), 1-9. https://doi.org/10.29332/ijssh.v1n2.26

Miles, M. B., \& Huberman, A. M. (1994). Qualitative Data Analysis: An Expanded Sourcebook (2nd ed.; R. Holland, Ed.). London: SAGE Publications.

Nurbudiyani, I. (2013). Pelaksanaan Pengukuran Ranah Kognitif, Afektif, dan Psikomotor pada Mata Pelajaran IPS Kelas III SD Muhammadiyah Palangkaraya [The Implementation of Cognitive, Affective, and Psychomotoric assesment on Social Science Subject of Third Grade Muhammadiyah Pa. Anterior Jurnal. https://doi.org/10.33084/anterior.v13i1.295

Putnam, R. F., Luiselli, J. K., Handler, M. W., \& Jefferson, G. L. (2003). Evaluating student discipline practices in a public school through behavioral assessment of office referrals. Behavior Modification, 27(4), 505-523. https://doi.org/10.1177/0145445503255569

Safina, R. N., \& Abdurakhmanov, M. A. (2016). The formation of students' tolerance in a multi-ethnic school. International Journal of Environmental and Science Education, 11(3), 269-277. https://doi.org/10.12973/ijese.2016.310a

Setiawan, A., \& Suardiman, S. P. (2018). Assessment of the social attitude of primary school students. Research and Evaluation in Education, 4(1), 12-21. https://doi.org/10.21831/reid.v4i1.19284

Stanford, K. B. (2017). Evaluating equity in student discipline: a program evaluation of positive behavior intervention and support in an elementary school setting (East Carolina University). Retrieved from http://thescholarship.ecu.edu/handle/10342/6212

Zuhera, Y., \& Mislinawati, H. (2017). Kendala Guru dalam Memberikan Penilaian terhadap Sikap Siswa dalam Proses Pembelajaran Berdasarkan Kurikulum 2013 di SD Negeri 14 Banda Aceh [The Teacher's Problem on Attitude Assesment Based on Curriculum in SDN 14 Banda Aceh Elementary School]. Jurnal Ilmiah Pendidikan Guru Sekolah Dasar FKIP Unsyiah, 2, 73-87. 